\title{
Barriers to co-operation and competitive advantage: cross- border business networks of Saxon and Northern Bohemian firms*
}

\author{
Birgit Leick**
}

Small-scale business co-operation across borders is considered as major driving force of economic integration between Western and Central Eastern Europe. In this context, it is argued that business co-operation and networks support the creation of competitive advantage. This paper sheds new light on this issue by adding a case study of firms in selected East German and Czech border regions. The study focuses on two inter-related research questions: Can firms create competitive advantage in small-scale business co-operation and networks within border regions? And what role is there for the barriers to cooperation that firms encounter? These questions are investigated using a dataset of nearly 60 structured interviews with firms from the cross-border regions.

In der Theorie kommt Unternehmenskooperationen und -netzwerken in Grenzräumen eine hohe Bedeutung bei der ökonomischen Integration der peripheren Regionen West- und Mittelosteuropas zu. Es wird angenommen, dass solche kleinräumigen Netzwerke einen wichtigen Beitrag zur Erhöhung der Wettbewerbsfähigkeit der Unternehmen in den zumeist wirtschaftlich strukturschwachen Regionen an der früheren EU-Außengrenze leisten. Der vorliegende Beitrag untersucht vor dem Hintergrund dieser Hypothese, ob Unternehmenskooperation und -netzwerke im Grenzraum tatsächlich die Wettbewerbsfähigkeit der beteiligten Unternehmen erhöhen und welche Rolle in diesem Zusammenhang Kooperationshemmnisse spielen. Als Fallbeispiel dient der Grenzraum Sachsen (Deutschland) - Nordböhmen (Tschechische Republik). Dem empirischen Teil liegt ein qualitativer Ansatz zugrunde; die Datenbasis besteht aus rund 60 Interviews mit Unternehmen in Sachsen und Nordböhmen.

Keywords: Cross-border business co-operation, competitive advantage, barriers to co-operation, Central Eastern Europe, East Germany

* Manuscript received: 21.06.10, accepted: 28.04.11 (1 revision)

** Birgitm Leick, Senior Lecture and Post-doctoral Researcher, Department of Economic Geography, Geographical Institute, University of Bayreuth, Germany. Main research interests: European border regions, international business theories and international management, regional cluster and networks, economix and firm development in East German and CEE economies, demographic change and business strategies. Corresponding address: birgit.leick@uni-bayreuth.de. 


\section{Introduction}

In the past, the effects of economic integration between Western and Central Eastern Europe (CEE) on border regions were discussed intensely in academia. The prevalent view argues that, in the long run, the border areas should benefit due to less or lower border impediments (Niebuhr/Stiller 2004). Specifically, small-scale business co-operation across borders is considered as major driving force of economic integration within border regions (Krätke 1999). In this context, it is argued that co-operative and network-type relationships enhance the competitiveness of firms - a rationale closely associated with a regional cluster view (Porter 2001). In addition, it has been acknowledged that sociocultural differences between actors from different nations may result in problems and barriers to internationalisation and can hinder successful foreign ventures. Despite the vast literature on this topic (Shaw/Darroch 2004; Wu et al. 2007), little is known about the micro-foundations of business networks spanning across the regions between Western and CEE countries, notably the barriers to collaboration and their importance to the competitive advantage.

To this end, the present study sheds new light on this issue by focussing on two inter-related research questions: Can firms create competitive advantage in business co-operation and networks within cross-border regions? And what role is there for the barriers to co-operation that firms encounter? These questions are investigated using a dataset of nearly 60 structured interviews with a comparative sample of firms from selected border regions of East Germany and the Czech Republic. The theoretical background of the present study adopts an integrative view on recent perspectives in regional economics and international business (IB).

The remainder of this article is organised as follows: After giving the theoretical considerations in Part 2, Part 3 presents the research setting and the methodology used. The empirical findings are described in Part 4. Finally, Part 5 discusses the results and gives the limitations to the study and some suggestions for future research.

\section{Theoretical considerations}

\section{Effects of economic integration on firms in European border regions}

With regard to Eastern European enlargement, traditional trade and location theories suggest that the opening up of border by means of political and economic integration translates into positive effects on adjacent firms in border areas, based upon three arguments. First, the geographical proximity of firms results in an increased market potential and easier access to nearby markets (Niebuhr/Stiller 2004). Secondly, due to a reduction of border impediments, i.e., barriers to trade and the abolition of political and administrative barriers, 
enterprises can benefit from lower transportation and transaction costs (Brenton/Manzocchi 2002). Thirdly, cost differences between Western and CEE countries may induce firms from the relative high-cost regions to seek business activities with enterprises from the low-cost regions in order to improve their cost position. Conversely, CEE firms can exploit new markets, given their comparative low-cost advantage.

However, in reality, border areas often exhibit substantial structural deficiencies that are only overcome in the long term perspective. This is highlighted, for instance, by relatively lower population densities, insufficient transport infrastructure, or an unfavourable industry and firm structure (see, for example, Krätke 1999 and Barjak/Heimpold 1999 for the German-Polish border area or Dimitrov et al. 2003 for the border regions between Greece, Albania, Bulgaria and the former Yugoslavia). For Eastern German and part of the Czech border areas, the majority of firms are small in size, and traditional manufacturing industries dominate the scene. Additionally, socio-cultural and language differences between residents and firms dissuade local actors from contacting and collaborating across borders. These differences are referred to as the "psychic distance" between actors from different cultural backgrounds (Johanson/Vahlne 1977/2003; Zanger et al. 2008). In particular, they are made accountable for the barriers to co-operation perceived by firms in the Single Market (Buigues/Jacquemin 1989; Kay 1991; Bröcker 1998). Specifically within border areas, another negative effect is linked to the fact that short distances to foreign markets may put pressure on local industries to adjust to new competitors (European Commission 2003). As a consequence, there are both positive and negative factors that shape the potential and success for cooperation between firms in the cross-border regions.

\section{Internationalisation of smaller firms within border regions}

The relevant theories on firm internationalisation therefore need to address the behaviour of the smaller firms, the type of businesses that often prevail in a border region context, as well as the specific characteristics of enterprises located in border areas. The process or stage model theories as well as the network approach to firm internationalisation are taken into account here as the most relevant streams of contemporary IB research that refer to network-type internationalisation strategies and (implicitly) point at the barriers to internationalisation.

\section{Smaller firms and internationalisation in a border region context}

The topics of why and how small to medium sized firms (SMEs) internationalise has been increasingly explored over the past years (Johanson/Vahlne 1990; Calof/Viviers 1995; Fillis 2001; Westhead et al. 2001; Bell et al. 2004). As "stylised facts", it is widely acknowledged that SMEs 
exhibit different behavioural patterns concerning internationalisation, especially when compared with larger corporations (Noteboom 1993; Coviello/McAuley 1999; Brouthers/Nakos 2004). They often lack the necessary resources for international activities, such as human capital, or financial and/or managerial resources. In many cases, they are not experienced in doing business abroad and lack knowledge of intercultural business-practices and skills. Accordingly, SMEs face environmental and behavioural uncertainty, and, consequently, higher risks when venturing abroad. As for their entry mode choice, SMEs often prefer exports to other types of foreign operations, and their commitment to foreign direct investment is rather limited (Cagusvil 1980; Buckley et al. 1988; Vatne 1995). However, they can benefit to a higher extent from the behavioural advantages of internationalisation than larger firms can. This argument is based on the higher entrepreneurial drive and mindset of small firms, their higher propensity of risk-taking, a motivated labour force combined with less bureaucracy, and a higher specialisation and flexibility (Noteboom 1993).

In addition to the particular patterns of internationalisation of smaller enterprises, the internationalisation choices of firms in border areas need to be considered separately. It has been observed that Eastern German firms - notably SMEs - entered CEE markets later than firms from other Western European regions (Ernst \& Young 2004). It has also been stated that Czech firms display a rather passive attitude and are not proactive, for example, with regard to foreign ventures, compared to Western European companies (Myant 1996). For the trans-border regions between the EU-15 and new CEE member countries, the pattern of internationalisation of firms shows that, in particular, smaller and local firms chose the co-operative strategies of entering neighbouring markets, rather than trade or investment activities, as could be observed, for example, for Austria (Fink/Kraus 2007), for Germany (Krätke 1999; Barjak/Heimpold 1999) or for selected CEE countries (Radosevic/Sadowski 2004). Hence, differences in speed of and preferences for market entry seem to be characteristic to the firms in "East West" cross-border regions.

\section{Process/stage theories of internationalisation}

The process/stage models of firm internationalisation can be traced back to the work of Johanson and Vahlne (1977/1990). The core concept explains international experience and learning as governing the pace and direction of subsequent internationalisation (DeClerq et al. 2005). Socio-cultural homogeneity (or heterogeneity) between the home market and foreign markets shapes the choices and the commitment of firms on domestic markets and abroad. Cultural distance is modelled as a composed variable of mainly qualitative factors (for example, differences in language, culture, managerial style, and business-practices, but also political and legal systems, macroeconomic trends, etc.) which account for a firm's notion of the homogeneity or heterogeneity of a foreign market (Johanson/Wiedersheim-Paul 1975). As a 
central proposition of the stage models, it is argued that, prior to foreign operations, firms gain experience on domestic markets (Etemad/Wright 2003). Then, they start internationalising by choosing culturally similar markets, for example, countries with the same language or similar business conventions. With the acquisition of knowledge of international markets and increasing experience, firms gradually raise their commitment in terms of investment or control within the existing arrangements, or they start venturing on markets with a greater cultural or "psychic" distance. The approach generally proposes a relationship between the intensity of foreign ventures and experimental knowledge developed through international experience (Johanson/Vahlne 1977; Contractor 2007; Steen/Liesch 2007).

The stage model approach has been often criticised. Major criticism relates to the empirical validity of the model, which is not fully consistent. For example, Bell et al. (2003) summarise that the sequential path does not fit the so-called "born global firms", and that it neglects industry specificity. Empirical studies show that other factors than "psychic distance" are responsible for the locational and organisational choices of internationalising enterprises, for instance, sectoral fitting with partner firms abroad (Bell 1995), market potential, the location of important customers or network relationships (Coviello/Martin 1999). Moreover, Meyer and Gelbuda (2006) point to the fact that smaller Western European firms started entering CEE markets with only little or no prior experience on those specific markets, which is evidence that speaks against the validity of the approach being used in this research.

Despite the criticism advanced, the stage/process theories of firm internationalisation underline the role of experimental learning for foreign ventures; this is linked, among other things, to the ability of firms to overcome barriers and to create market-specific knowledge (Johanson/Vahlne 2003, DeClerq et al. 2005, Zanger et al. 2008). Implicitly, the relevance of barriers to internationalisation is acknowledged at all stages of an ideal-type gradual internationalisation process.

\section{Network theories of internationalisation}

The emergence of network-based enterprise structures has been explained across disciplines (Porter 1990; Krugman 1991; Dunning 2000; Johanson/Vahlne 2003; Dunning/Lundan 2008). In an internationalisation context, the network approach posits that firm internationalisation is driven by network relationships (Coviello/Munro 1997; Coviello/McAuley 1999; Cantwell/Piscitello 1999; Chetty/Blankenburg Holm 2000). Network-based collaboration is considered particularly beneficial for smaller enterprises (Coviello/McAuley 1999; Lu/Beamish 2001; Hollenstein 2005). Network relationships provide firms with access to complementary resources, and facilitate the exploitation of economies of scale/scope and synergies. Moreover, 
networks offer competitive advantage through a reduction of transaction costs, risk-sharing or enhanced knowledge creation/transfer among participating firms. Zain and $\mathrm{Ng}$ (2006) also show that integration in business networks may motivate enterprises that have so far only served domestic markets to internationalise for the first time. Despite the obvious benefits of network-type relationships for foreign ventures, network risks can pose a constraint on a firm's competitive advantage achieved through cross-border relations. Network risks are associated with opportunism of foreign enterprises seeking individual benefits at the cost of their partner firms (Williamson 1975; Hennart 1993). In cross-cultural relationships, opportunism is linked to uncertainty about foreign markets and partners. In "East-West"-networks, socio-cultural differences between co-operative partners, as potential risks, can lower the competitive advantage gained through collaborative relationships. In a worst case scenario, "strong" relationships and power asymmetries within the network may translate to dependence, for example, on large or technologically more advanced partners; this poses a risk for a firm's ability to look out for other, more "valuable" partners outside the network and for its future strategies such as industrial upgrading (Chetty/Campbell-Hunt 2003; Radosevic/Sadowski 2004). Network risks in conjunction with opportunistic behavior of foreign partners are particularly evident in small number relationships, i.e., when there are only a few alternative partners available due to asset specificity (Hennart 1993). Moreover, as relationships are built up through personal contacts, many SMEs, in practice, are not involved in networks abroad (O'Grady/Lane 1996). Thus, important pre-requisites for successful networking that increases the firms' competitive advantage are mutual relationship commitment and trust-building of network partners, along with the development of experience on foreign markets (Hennart 1993; Fink/Kraus 2007; Wu et al. 2007).

\section{Co-operation and competitive advantage}

The notion of competitive advantage draws heavily from a resource-based perspective. This view posits, in essence, that a firm's internal resources and capabilities are critical towards achieving sustained competitive advantage (Wernerfelt 1984; Barney 1991). As a rule, only critical or strategic resources are considered to be relevant for shaping the competitive advantage (Rangone 1999). In the more recent IB literature, it is argued that enterprises venturing abroad need to make use of their internal resources in order to build up and to use firm-specific competitive advantage on foreign markets (Peng 2006; Söllner 2007). From this perspective, networking is seen as a strategy for obtaining critical resources and, hence, creating value through relationships. Similarly, Porter's "diamond" concept of competitiveness proposes that a firm's competitive advantage is shaped, among other key factors, by its operating environment, notably as the localisation of related and supporting industries (Porter 1990/2001). Porter acknowledges that network-type relations between 
industries and firms determine micro-level competitiveness. Accordingly, cooperative activities are seen as a strategic option for firms that wish to strengthen their competitive position (Kotha et al. 2001). Thus, firms engage in co-operative arrangements even though, or even if, co-operation takes place with competitors. The present article follows the idea that the cross border network-based relationships can build up or enhance the competitive advantage of the participating firms.

\section{Research setting, methodology and working definitions}

\section{Research setting and methodology}

The empirical part is based on the analysis of multiple case studies and adopts a qualitative approach in order to gain in-depth insight into the phenomena under investigation and to highlight important features, differences and communalities of the cases. Exploratory in its approach, the study aims to analyse the proposed research questions without an underlying quantitative model. Afterwards, research hypotheses on the topic will be derived as conclusions.

Table 1. Co-operating versus non-co-operating sample firms

\begin{tabular}{|l|c|c|}
\hline & $\begin{array}{c}\text { Saxon sample } \\
(\mathrm{N}=29)\end{array}$ & $\begin{array}{c}\text { Northern Bohemian } \\
\text { sample (N = 27) }\end{array}$ \\
\hline $\begin{array}{l}\text { Firms with co-operative arrangement(s) with } \\
\text { Czech/German company within cross-border } \\
\text { region }\end{array}$ & 14 & 14 \\
\hline $\begin{array}{l}\text { Firms with co-operative arrangement(s) with } \\
\text { Czech/German company outside cross- border } \\
\text { region }\end{array}$ & 4 & 13 \\
\hline Firms without such co-operative arrangement(s) & 11 & 4 \\
\hline
\end{tabular}

Multiple responses allowed. Source: Own survey 2004/2005

Two cross-sectional datasets stemming from postal surveys with firms from Saxony (Germany) and Northern Bohemia (Czech Republic) during Eastern European enlargement were used as the point of departure for case selection as non-random samples. The research setting results from a two-stage selection process, which met two important criteria (see Leick 2007 for a comprehensive depiction of the case selection process and the case study findings). The first selection criterion pertains to the firms' involvement in cross-border cooperative arrangements (Table 1). In this study, only enterprises engaged in cooperative arrangements will be analysed. Then, firms were classified according to their industry (Table 2). Since it has been acknowledged that the degree to 
which economic integration affects firms varies across industries (European Commission 2003), sectors that were expected to be affected positively and negatively were included. The empirical fieldwork consisted of personal interviews with interlocutors at the CEO, managing director, and leading business manager or owner level, conducted during 2004/2005. A semistructured questionnaire with both structured and open-ended questions in German and Czech was used.

Table 2. Industry affiliation of sample firms

\begin{tabular}{|l|c|c|}
\hline & $\begin{array}{c}\text { Saxon sample } \\
(\mathrm{N}=29)\end{array}$ & Northern Bohemian sample (N = 27) \\
\hline Manufacturing industries & 15 & 2 \\
\hline Construction & 3 & 2 \\
\hline Wholesale trade & 5 & 4 \\
\hline $\begin{array}{l}\text { Production-related } \\
\text { services }\end{array}$ & 6 & \\
\hline
\end{tabular}

Source: Own survey 2004/2005

\section{Working definitions}

The working definition of business co-operation used in this study follows transaction costs economics. Williamson $(1975,1991)$ explains relational transactions as constituting an alternative option for firms to use either fully market-based or internal transactions. As a result, we consider co-operative relationships as a wide range of diverse long-term inter-firm relational arrangements between the spot market and hierarchical integration of firms. This broad definition addresses the most important criteria that are attributed to business network relationships as proposed in transaction cost economics and allows us to capture a variety of co-operative relationships.

With regard to the competitive advantage of the firms, it is assumed that the competitiveness of firms through business co-operation is associated with the extent to which they achieve specific targets through collaboration. Accordingly, achieving co-operative targets translates to successful collaboration that is conceptualised as a multi-dimensional construct encompassing two different categories of targets, "economic" and "noneconomic" targets (Table 3). This setting follows a benchmark study by Kaufmann et al. (1990) on the effects of the Single Market on firms within adjacent regions (Contractor/Lorange 1988). 
Table 3. Operationalisation of the competitive advantage gained through cooperation

\begin{tabular}{|c|c|c|}
\hline $\begin{array}{l}\text { Group of co-operative } \\
\text { targets }\end{array}$ & $\begin{array}{l}\text { Target } \\
\text { achieved due to } \\
\text { co-operation }\end{array}$ & $\begin{array}{l}\text { Single items given in the questionnaire (with } \\
\text { open-ended, in-depth questions afterwards) }\end{array}$ \\
\hline \multirow{2}{*}{$\begin{array}{l}\text { Economic targets } \\
\text { direct reference to the } \\
\text { firm's competitive } \\
\text { position }\end{array}$} & Cost reduction & $\begin{array}{l}\text { - Access to low-cost import markets } \\
\text { - Outsourcing of cost-intensive tasks } \\
\text { - Higher degree of capacity utilization } \\
\text { - Accomplishing tasks that were not } \\
\text { possible formerly } \\
\text { - Utilizing economies of scope } \\
\text { - Other item (with respect to cost } \\
\text { reduction) }\end{array}$ \\
\hline & $\begin{array}{l}\text { Revenue } \\
\text { increase }\end{array}$ & $\begin{array}{l}\text { - Cheaper or new distribution/export } \\
\text { channels } \\
\text { - } \text { Diversification of product/service range } \\
\text { - } \text { Fast market entry } \\
\text { busing use of new market knowledge or } \\
\text { - Other item (with respect to revenue } \\
\text { increase) }\end{array}$ \\
\hline \multirow{2}{*}{$\begin{array}{l}\text { Non-economic targets } \\
\text { indirect reference to the } \\
\text { firm's competitive } \\
\text { position }\end{array}$} & Risk reduction & $\begin{array}{l}\text { - Reducing competitive/pricing pressure } \\
\text { - Diversification of product/service range } \\
\text { - Other item (with respect to risk } \\
\text { reduction) }\end{array}$ \\
\hline & Other targets & $\begin{array}{l}\text { - } \text { Transfer of know-how/knowledge } \\
\text { - Synergy effects for specific production } \\
\text { stages } \\
\text { - } \quad \text { Qualifying employees } \\
\text { - Overcoming barriers to co-operation } \\
\text { - Other item (with relevance for co- } \\
\quad \text { operative success) }\end{array}$ \\
\hline
\end{tabular}

Own illustration

It considers both easily measurable and quantitative "economic" targets and "non-economic" targets that are more difficult to measure, primarily qualitative in their nature, but highly relevant for the co-operative activities of Western and CEE enterprises. The targets have been specified as: cost reduction; increase of revenue; risk reduction; and other targets. As shown by Table 3, they have been split up into sub-items and open-ended, additional items that were to be specified by the interviewees. In addition to the framework proposed by Kaufmann et al. (1990), it is argued here that the targets "reducing costs" and 
"increasing revenue", as co-operative success, refer directly to the competitive position of co-operating firms. Moreover, "non-economic" co-operative targets are included in the model (for example, reduction of risks associated with foreign ventures or network risks such as power asymmetries and strong dependence on foreign partners; overcoming barriers to collaboration respectively targets that refer to industrial upgrading of collaborating firms). They only indirectly refer to the firm-level competitive advantage gained through co-operation, but crucially shape the success of cross-border collaboration.

\section{Measuring barriers to co-operation}

The relationship between barriers to internationalisation and the pattern of firm internationalisation is a topic of interest in several recent studies (for example, Shaw/Darroch 2004; Aidis 2005; Bhardwaj et al. 2007; Welch/Welch 2008). Different classifications and methodologies are used in the literature. In the present study, we distinguish five different types of barriers:

- Barriers related to internal resources of firms (for example, financial problems or a lack of experienced personnel for foreign ventures, etc.); they are associated with the size and the organisational constraints of firms.

- Barriers associated with collaboration (for instance, the divergent cooperative targets of firms, the specifications of contracts, problems with opportunistic behaviour of partners, output-related problems such as quality deficits); these barriers pertain to the network risks as proposed by transaction cost theory (Williamson 1975; Hennart 1993).

- Barriers external to the firm and the co-operation (for example, macroeconomic factors, the legal and administrative environment or a high level of bureaucracy).

- Informational deficits: these deficits are not only linked to a lack of general information and know-how on internationalisation, but also to specific knowledge on foreign markets, competitors, industry, etc. A lack of knowledge creates uncertainty and reduces the propensity of firms to start venturing abroad. Moreover, it constitutes an important barrier for firms seeking intensified, deeper co-operation or starting new projects. This type of barrier partly corresponds to the firm's endowment with internal resources. As pre-test interviews identified informational deficits as a significant barrier, their role is examined separately.

- Socio-cultural differences: these differences and - as a result - problems typically comprise not only a language barrier, differences in mentality, and habits and tradition, but also in corporate culture, managerial and leadership style. Socio-cultural differences which function as a barrier to co-operation partly correspond to the "psychic distance" as modelled in 
the stage/process models. This barrier refers to the diverging social norms of firms from former state socialism versus Western Europe (Meyer/Gelbuda 2006).

The existence and role for barriers is explored via open-ended questions. Moreover, firms were asked whether overcoming barriers to co-operation was linked to the perception of greater co-operative success.

\section{Evidence from the case studies}

The empirical findings from the interviews are presented across-cases, comparing groups of responses according to the patterns observed. A depiction of single cases in detailed narrative will be forgone in this article (see Brezinski/Leick 2005). Table 4 gives the profiles of the 56 case firms, highlighting that the majority of the firms are small and medium sized enterprises.

Table 4. Profiles of Saxon and Northern Bohemian firms

\begin{tabular}{|c|c|c|c|}
\hline Saxon firms & & Northern Bohemian firms & \\
\hline Legal form & $\mathrm{N}=29$ & Legal form & $\mathrm{N}=27$ \\
\hline $\begin{array}{l}\text { Gesellschaft mit beschraenkter } \\
\text { Haftung }(\mathrm{GmbH})(\sim \text {,limited } \\
\text { liability company“ })\end{array}$ & 22 & $\begin{array}{l}\text { Akciová společnost } \\
\text { ( “joint stock company”) }\end{array}$ & 8 \\
\hline $\begin{array}{c}\text { GmbH \& Co. KG } \\
\text { (subtype of limited liability } \\
\text { company/limited partnership) }\end{array}$ & 3 & $\begin{array}{l}\text { Společnost s ručením omezeným } \\
\text { (s.r.o.) } \\
(\sim \text {, ,imited liability company“) }\end{array}$ & 15 \\
\hline OHG ( „general partnership“) & 1 & $\begin{array}{c}\text { Soukromá osoba ( “sole } \\
\text { proprietor”) }\end{array}$ & 2 \\
\hline \multirow[t]{2}{*}{$\begin{array}{l}\text { Einzelunternehmen/eingetragener } \\
\text { Kaufmann ( „sole proprietor“) }\end{array}$} & 3 & $\begin{array}{l}\text { Komanditní společnost } \\
\text { ( “limited partnership”) }\end{array}$ & 1 \\
\hline & & Družstvo ( “co-operative”) & 1 \\
\hline Corporate integration & $\mathrm{N}=29$ & Corporate integration & $\mathrm{N}=27$ \\
\hline Independent firm & 20 & Independent firm & 18 \\
\hline Subsidiary of domestic corporation & 5 & Subsidiary of domestic corporation & 2 \\
\hline Subsidiary of foreign corporation & 4 & Subsidiary of foreign corporation & 7 \\
\hline Total employees & $\mathrm{N}=29$ & Total employees & $\mathrm{N}=27$ \\
\hline
\end{tabular}




\begin{tabular}{|c|c|c|c|}
\hline$<10$ & 6 & $<10$ & 3 \\
\hline $10-50$ & 6 & $10-50$ & 5 \\
\hline $51-100$ & 8 & $51-100$ & 7 \\
\hline $101-250$ & 5 & $101-250$ & 2 \\
\hline $251-500$ & 4 & $251-500$ & 5 \\
\hline & & $>500$ & 5 \\
\hline
\end{tabular}

Source: Own survey 2004/2005

\section{Successful co-operation and competitiveness: Reasons, explanations and limitations}

A first area of study is the question of whether firms gain competitive advantage through co-operation. As for Saxon case firms, 11 out of 18 interviewees of firms with co-operative arrangements indicate successful co-operation. With regard to "economic" targets and co-operative success, in seven cases, the interviewed managers stated that their firms successfully achieved a cost reduction. It is interesting to note that the typical governance modes, then, are outward processing trade and sub-contracting agreements with Czech firms or imports from the Czech Republic. Two firms further reported that they had reduced their production costs within a business network with several firms from Germany, the Czech Republic and other CEE and Western European countries. Apart from cost reductions, these firms successfully gained access to CEE export markets using network relationships. In a different seven cases, the interviewees stated that they had increased their revenue within co-operative arrangements. This was due to the fact that their relationships with Czech firms had opened the doors for new business contacts or had helped them to gain specific market knowledge, as they reported in four cases. Three firms indicated a successful expansion of their product or service range that led to higher revenue.

With regard to "non-economic" co-operative targets, in three cases, the managers in Saxony reported that their companies had reached a risk reduction. Two of the firms managed to reduce the risk of venturing in CEE countries by using the informal networks of several enterprises from Germany and CEE countries. They also claimed that they had increased their flexibility and diversified their products/services. Moreover, in four cases, firms reported that barriers to co-operation were successfully reduced in the course of their cooperation with Czech enterprises. Finally, one interviewee stated that the generation of market-specific knowledge was a key factor to achieve cooperative success. 
18 of 23 Northern Bohemian enterprises indicated successful co-operative relationships with Saxon/German firms. They specifically benefitted from achieving "economic" targets. In 13 cases, respondents reported a revenue increase due to an expansion of their range of products or services offered. Four interviewees asserted that a fast market entry in Saxony and Germany implied higher revenue. Moreover, in seven cases, revenue increase had been achieved by making use of new business contacts and references of their partners. Additionally, in seven cases, Czech firms reported a reduction of production costs due to co-operation or network-type relationships with Saxon/German firms. The co-operation relied on Czech enterprises importing (semi-)finished goods either from single partner firms (in three cases) or within business networks (in two cases). This finding is interesting since it highlights that the prevalent pattern of "East-West"-collaboration with Western European firms seeking to exploit low-cost advantages might be reversed in individual cases.

With regard to "non-economic" co-operative targets and success, the Czech interviewees most often indicated a successful risk reduction. The respondents explained this effect with the fact that they had entered a foreign market for the first time or successfully expanded their foreign operations in Saxony (in four cases). As a consequence, these firms became less dependent on domestic or foreign key accounts and owners. Moreover, the firms reported a risk reduction by virtue of lower pricing pressure (in two cases) or a broader range of products (in three cases). In other cases, co-operative success was achieved by means of a transfer of knowledge from Saxon/German to the Czech partner firms (in nine cases) or through the qualification of their human capital (in eight cases). In these cases, however, knowledge transfer and human capital qualification were only initiated by Saxon/German business partners. Finally, in five cases, the Northern Bohemian respondents stated that successful co-operation was associated with the initial barriers between co-operation partners that had been successfully overcome.

As for the cases where co-operation had not been successful, five of 18 interviewees in Saxony indicated a lack of co-operative success. These respondents gave a list of explanations of why this was the case. In two cases, the lack of success was linked to low shares of export turnover in Czech markets relative to total export turnover. Two firms claimed that the fierce competition with Czech subsidiaries or partner firms inside a corporate structure was responsible for the failure. It is interesting to note that, particularly for the collaboration of Saxon and Czech subsidiaries or for the economically dependent firms of multinational corporations, the interviewees from Saxony indicated a rise in competitive pressure exerted by Czech partner firms, and, consequently, a higher risk, both in terms of entrepreneurial risk and the risk associated with foreign operations. This constellation applies to cases in which the Saxon subsidiaries were originally set up as so-called "extended workbenches". The cost differences between the Saxon and Czech locations, 
and, accordingly, the resulting division of labour of the firms account for a rise in entrepreneurial risk for Saxon firms in these cases. Consequently, cooperative and network strategies do not support the creation of competitive advantage by strengthening - directly or indirectly - the competitive position of Saxon firms.

As for the Northern Bohemian sample, four of 23 firms indicated that their cooperation had not been successful. They listed several causes for the lack of success, for example low export shares in Saxon/German markets, unfair payment practices on the part of their business partners or a lack of recognition of their domestic brands abroad (one case each). In the case of a company that established a subsidiary in Western Germany, differences in mentality, corporate culture and managerial style, as well as German employment laws and collective bargaining provisions, had prevented successful co-operation, according to the respondent. In a second striking case, the interviewee reported that Saxon partner firms had become competitors on domestic Czech markets as a consequence of their co-operation. These findings highlight that the barriers to co-operation partially account for a lack of co-operative success.

\section{Relevance and role of barriers to co-operation}

Tables 5 and 6 summarise the barriers to co-operation as given by the enterprises. In six cases, interviewees from Saxony stated that the barriers to cooperation referred to difficulties in entering Czech markets or in establishing long-term relationships with Czech firms. According to the respondents, the main reasons for these difficulties were the differences in mentality, corporate culture and managerial style between German and Czech business partners. Moreover, different languages used, a low adherence to fixed delivery dates by Czech firms, an inferior quality of the Czech products and services delivered and informational deficits with regard to potential (new) partner firms, customers, and suppliers were impediments to co-operative relationships, from the viewpoint of the Saxon enterprises. In particular, a lack of mutual interpersonal trust is given as a striking barrier to co-operation during the initial stages of co-operative relationships.

Notwithstanding this, the respondents from Saxony explained that many of these problems and barriers were overcome in the course of their co-operation. Typically, these firms were then involved in long-term trade or production relationships with Czech firms, or they held shares in the Czech firms, founded or took over enterprises in Northern Bohemia and/or in the Czech Republic. According to the interlocutors, the fact that initial barriers were overcome is reflected in the improvements in quality of the Czech products, a higher adherence to fixed dates and a higher trustworthiness of their Czech partners.

In spite of these observations, the interviewees still perceive barriers that lower co-operative success and persist over time. In four cases, they reported 
informational deficits specifically with regard to the search for (other or new) partner firms. Other barriers include exchange rates and price fluctuations (in three cases), a lack of qualified managerial staff in Northern Bohemian/Czech partner firms (in two cases), a lack of innovation on the part of their partners (in two cases), and, as an individual issue, lack of transparency of their ownership structures. In addition, three Saxon firms with Czech subsidiaries reported a low flexibility and personal mobility of Czech employees as a general problem of their activities on the Czech market.

\section{Table 5. Co-operative barriers from the Saxon firms' viewpoint}

\begin{tabular}{|l|c|}
\hline Barrier to co-operation & $\mathrm{N}=32$ \\
\hline Differences in mentality, corporate culture and managerial style & 4 \\
\hline Different languages & 4 \\
\hline Informational deficits & 3 \\
\hline $\begin{array}{l}\text { Lack of potential co-operative partner firm(s) in Northern Bohemia/in the } \\
\text { Czech Republic }\end{array}$ & 3 \\
\hline $\begin{array}{l}\text { Monetary uncertainty, e.g., due to fluctuations of raw material or energy } \\
\text { prices and/or exchange rates }\end{array}$ & 2 \\
\hline $\begin{array}{l}\text { Uncertainty due to a change of ownership/management of the Northern } \\
\text { Bohemian/Czech partner firm(s) }\end{array}$ & 2 \\
\hline $\begin{array}{l}\text { Lack of innovativeness and flexibility on the part of the Northern } \\
\text { Bohemian/Czech employees }\end{array}$ & 2 \\
\hline $\begin{array}{l}\text { Lack of product quality and punctuality on the part of the Northern } \\
\text { Bohemian/Czech partner firm(s) }\end{array}$ & 2 \\
\hline Lack of qualified personnel for the Northern Bohemian/Czech subsidiary & 1 \\
\hline Financial risk & \\
\hline
\end{tabular}

Multiple responses allowed. Source: Own survey 2004/2005

Similarly, for the Northern Bohemian interviewees, many barriers to cooperation accounted for an initially low or lack of success in co-operation. The respondents gave several reasons which partly corresponded to the pattern of explanations given by Saxon firms. In four cases, they reported a long-standing process of trust-building between firms. Other causes are high requirements by Saxon/German companies with regard to the quality and punctuality of delivery (in four cases) and the language barrier (in two cases). 
Table 6. Co-operative barriers from the Northern Bohemian firms' viewpoint

\begin{tabular}{|l|c|}
\hline Barrier to co-operation & N $=28$ \\
\hline Informational deficits & 7 \\
\hline $\begin{array}{l}\text { Difficulties with payment practices/procedures on the part of the Saxon/German } \\
\text { partner firm(s) }\end{array}$ & 4 \\
\hline $\begin{array}{l}\text { Lack of personal contacts for market entry/penetration or for deepening existing } \\
\text { co-operation }\end{array}$ & 4 \\
\hline Pricing pressure exerted by the Saxon/German partner firm(s) & 3 \\
\hline $\begin{array}{l}\text { Administrative barriers and high level of bureaucracy with the Saxon/German } \\
\text { partner firm(s) }\end{array}$ & 2 \\
\hline Different languages & 1 \\
\hline Differences in mentality, corporate culture and managerial style & 1 \\
\hline $\begin{array}{l}\text { High requirements regarding product quality by the Saxon/German partner } \\
\text { firm(s) }\end{array}$ & 1 \\
\hline Difficulties in entering Saxon/German markets & 1 \\
\hline $\begin{array}{l}\text { Difficulties in building up mutual trust or mistrust on the part of the } \\
\text { Saxon/German partner firm(s) }\end{array}$ & 1 \\
\hline Lack of qualified personnel for the Saxon/German subsidiary & 1 \\
\hline Lack of qualified personnel for the Czech subsidiary & 1 \\
\hline Difficulties with a take-over of the Saxon/German firm & 4 \\
\hline
\end{tabular}

Multiple responses allowed. Source: Own survey 2004/2005

Although they also stated that most of these difficulties had been overcome in the course of time, the Northern Bohemian firms acknowledge the existence of more persistent barriers. In seven cases, they indicated informational deficits between business partners, within the context of searching for other partner firms or with regard to legal and administrative information. Moreover, problems with payment practices with Saxon/German customers (in four cases) and difficulties in accessing these markets outside sub-contracting agreements (in three cases) were reported. In addition, in two cases, firms indicated that they were not able to deepen or further develop their co-operation in order to reduce dependencies on their Saxon/German partners within sub-contracting agreements. Other aspects given related to a lack of or only a low recognition of Czech brands on foreign markets (in two cases), the pressure exerted by the 
Saxon/German customers to force the Czech firms to lower their prices (in three cases), a lack of qualified personnel in Germany and the Czech Republic (in one case), difficulties with a take-over of a German firm (in one case) and a high level of bureaucracy in Germany (in one case).

\section{Discussion of results, conclusions, future research directions and limitations}

The case analysis reveals that both "economic" and "non-economic" success criteria as the achievement of co-operative targets matter for co-operation within the border region. Competitive advantage is gained through co-operation that strengthens the competitive position of Saxon and Northern Bohemian firms directly and indirectly. In detail, several salient features of cross-border co-operation can be highlighted.

First, the typical pattern of co-operation based on making use of the cost differences between Germany and the Czech Republic dominates the cases. Typically, Saxon firms successfully reduce their production costs through collaboration. Strikingly, the results hint at a similar pattern for Czech enterprises in individual cases. As a second phenomenon observed for both groups of firms, network-type relationships between more than two firms are clearly beneficial for achieving co-operative success in terms of cost reductions and revenue increase by entering new export markets or facilitating market entry. Another important finding is that, in particular, Saxon firms benefitted from collaboration through new business contacts and increasing market knowledge. This observation corresponds to the finding that informational deficits as one important barrier to co-operation become less important in the course of co-operation. For the Northern Bohemian case firms, entrepreneurial and industrial upgrading is additionally facilitated by virtue of product range expansion. In summary, those aspects seem to be associated with gains made through a faster, easier access to neighbouring markets.

Thirdly, a reduction of risks linked to entrepreneurial functions and/or foreign ventures plays an important role for creating competitive advantage through cooperation. Saxon firms successfully lowered these risks within network relationships in Czech and other CEE markets; they gained from flexibility and a diversification of their activities. Moreover, risk reduction is associated with a decrease in the importance of barriers to co-operation. Barriers pertain, again, to the generation of market knowledge. This phenomenon is observed for Saxon and Northern Bohemian firms alike. For Czech enterprises, indirect effects on their competitiveness in terms of human capital qualification and knowledge transfer initiated by Western European partner firms also matter. Czech case firms reduced entrepreneurial risks within cross-border co-operation by means of diversification and lower dependency on the home market. This observation hints at the process of adjusting entrepreneurial functions in Czech enterprises 
to market-based economies. These cases indicate strong network benefits that clearly prevail over potential collaborative risks.

Lastly, the results allow us to identify constellations that are not or less beneficial towards achieving competitive advantage as compared to the latter constellations. One type of co-operation is influenced by the corporate structures of the collaborating firms, typically as economically dependent, sometimes wholly/majority owned subsidiaries established as workbenches. A second pattern is associated with co-operative partners that turned into competitors while collaborating. Although co-operation by definition implies competition between firms, in these cases, rising competitive pressure affects co-operative success adversely. Both constellations hint that strong network risks (such as opportunistic behaviour of partners) lower or prevent collaborative success. Moreover, both very shallow and deep integration does not support the competitive advantage gained through collaboration. In the first case, it is observed that, for example, low shares of export turnover to neighbouring markets in relation to total export turnover do not affect the competitive position of the exporting firm at all. In the latter case, socio-cultural differences and administrative regulations impede the successful establishment or the foundation of subsidiaries abroad.

The results evoke the question of the relevance of barriers to co-operation for these patterns and processes. The case findings reveal that barriers to cooperation clearly shape the competitive position of firms within co-operative agreements, but need to be analysed in a process perspective. To some extent, the barriers to co-operation that firms initially perceive are reduced or overcome during co-operation; this is accompanied by greater co-operative success. Particularly barriers that relate to the internal resources of the firms, or are external to the firm and the co-operation are not very relevant for the cooperative activities under review. In contrast, barriers associated with the cooperation, informational deficits and socio-cultural differences, are more important. The empirical results show that socio-cultural aspects play a crucial role: this is reflected in a vague notion of informational deficits, a lack of mutual trust or a low trustworthiness on the part of foreign partners. The fact that these factors act as barriers for firms willing to co-operate fits the concept of "psychic distance" between actors from different nations, as proposed in stage models of internationalisation. In the longer run, normalisation in the relationships clearly takes place: typically, firms develop higher levels of trust, or the significance of informational deficits decreases. Therefore, this research particularly suggests that the development of mutual trust among partners is a crucial pre-requisite of collaborative success. From a managerial viewpoint, building trust-based networks can be effectuated through several actions. Frequent face-to-face interaction along with highlighting similarities among entrepreneurs, for example, in peripheral environments, creates familiarity. Besides (long-term) commitment, reliability and credibility of partners, it is 
essential to add depth to "East-West"-collaborative networks (for example, subcontracting agreements) by adopting a new setting with partners. Quality improvements on the part of Northern Bohemian enterprises and informationsharing on the part of Saxon firms support reputation-building and the development of trust-based co-operation. Again, the validity of a learning process while co-operating is confirmed, as explained by the process/stage model approach. Another significant result, however, is that persistent barriers to co-operation account for a low or even a lack of success. They are associated with socio-cultural differences, but are also to be found for the deep integration of firms and, hence, persistent network risks. There is also evidence which suggests that, in some cases, Northern Bohemian companies are "locked" in existing relationships and are not able to deepen co-operation or access markets outside processing trade agreements.

What lessons can be learnt from this analysis? The case studies presented offer a broad view on the competitive advantage created through collaboration, the barriers to co-operation and the potential inter-relationship between the two phenomena. In summary, this study allows us to formulate the following research propositions:

Competitive advantage through "East-West"-collaboration is gained by means of overcoming barriers to co-operation;

Governance types matter: neither very shallow nor very deep integration is supportive of achieving competitive advantage in collaborative relationships of Western European and CEE firms;

Network-type relationships are the ideal-type organisational form of cooperation between these firms in order to gain competitive advantage directly and indirectly.

As for future research directions, the methodological framework proposed may serve as a blueprint for measuring the impact of co-operative activities on firm competitiveness with other border regions within the enlarged European Union. Furthermore, a process perspective might enhance the understanding of the changing relevance of collaborative barriers. However, some limitations of the study should be taken into account as well. One limitation relates to the emerging fuzziness of the definitions proposed for measuring co-operation as well as the competitive advantage. Although this paper provides comprehensive insight into the research question as discussed, the findings are moreover not generalisable due to methodological limitations and small sample sizes. As exploratory research, and since the results and the effects observed cannot be quantified using case study methods, the phenomena explored should therefore be validated with subsequent, quantitative research. 


\section{References}

Aidis, R. (2005): Institutional barriers to small- and medium-sized enterprise operations in transition countries, in: Small Business Economics, 25, 4, 305-318.

Barjak, F./Heimpold, G. (1999): Development problems and policies at the German border with Poland: regional aspects of trade and investment. Discussion Paper, 101. Halle: Institut für Wirtschaftsforschung Halle.

Barney, J.B. (1991): Firm resources and sustained competitive advantage, in: Journal of Management, 17, 1, 99-120.

Bell, J. (1995): The internationalisation of small software firms: a further challenge to the 'stage theories', in: European Journal of Marketing, 29, 8, 60-75.

Bell, J./Crick, D./Young, S. (2004): Small firm internationalisation and business strategy: an exploratory study of 'knowledge-intensive' and 'traditional' manufacturing firms in the UK, in: International Small Business Journal, 22, 1, 23-56.

Bell, J. (ed.) (2003): Towards an integrative model of small firm internationalisation, in: Journal of International Entrepreneurship, 1, 4, 339-362.

Bhardwaj, A./Dietz, J./Beamisch, B.W. (2007): Host country cultural influences on foreign direct investments, in: Management International Review, 47, 1, 29-50.

Brenton, P./Manzocchi, S. (2002): Enlargement, trade and investment: a review of economic impacts, in: Brenton, P./Manzocchi, S. (eds.): Enlargement, trade and investment: the impact of barriers to trade in Europe, Cheltenham: Edward Elgar, 10-37.

Brezinski, H./Leick, B. (2005): Kooperationsperspektiven südwestsächsischer und tschechischer Unternehmen: Eine Analyse auf der Basis von Unternehmensbefragungen im erweiterten Binnenmarkt. Freiberg: Technische Universität Freiberg.

Bröcker, J. (1998): How would an EU-membership of the Visegrád-countries affect Europe's economic geography?, in: Annals of Regional Science, 32, 1, 91-114.

Brouthers, K.D./Nakos, G. (2004): SME entry mode choice and performance: a transaction cost perspective, in: Entrepreneurship Theory and Practice, 28, 3, 229-247.

Buckley, P.J./Newbould, G.D./Thurwell, J.C. (1988): Foreign direct investment by smaller U.K. firms: the success and failure of first-time investors abroad, London: MacMillan.

Buigues, P./Jacquemin, A. (1989): Strategies of firms and structural environments in the large internal market, in: Journal of Common Market Studies, 28, 1, 53-67.

Cagusvil, S.T. (1980): On the internationalisation process of firms, in: European Research, 8, 6, 273-281.

Calof, J.L./Viviers, W. (1995): Internationalisation behaviour of small and medium-sized South African enterprises, in: Journal of Small Business Management, 33, 3, 71-79.

Cantwell, J./Piscitello, L. (1999): The emergence of corporate international networks for the accumulation of dispersed technological competences, in: Management International Review, 39, special issue 1, 123-147.

Chetty, S./Blankenburg Holm, D. (2000): Internationalisation of small to medium-sized manufacturing firms: a network approach, in: International Business Review, 9, 1, 7793. 
Chetty, S./Campbell-Hunt, C. (2003): Explosive international growth and problems of success amongst small to medium-sized firms, in: International Small Business Journal, 21, 1, $5-27$.

Contractor, F.J. (2007): Is international business good for companies? The evolutionary or multi-stage theory of internationalisation vs. the transaction cost perspective, in: Management International Review, 47, 3, 453-475.

Contractor, F.J./Lorange, P. (1988): Co-operative strategies in international business. Lexington: D.C. Heath.

Coviello, N.E./Martin, K.A.M. (1999): Internationalisation of service SMEs: an integrated perspective from the engineering consulting sector, in: Journal of International Marketing, 7, 4, 42-66.

Coviello, N.E./McAuley, A. (1999): Internationalisation and the smaller firm: a review of contemporary empirical research, in: Management International Review, 39, 3, 223 256.

Coviello, N./Munro, H. (1997): Network relationships and the internationalisation process of small software firms, in: International Business Review, 6, 4, 361-386.

DeClerq, D./Sapienza, H.J./Crijns, H. (2005): The internationalisation of small firms, in: Small Business Economics, 24, 4, 409-419.

Dimitrov, M. (ed.) (2003): Cross-border co-operation in Southeastern Europe: the enterprises' point of view, in: Eastern European Economics, 41, 6, 5-25.

Dunning, J.H. (2000): The Eclectic paradigm as an envelope for economic and business theories of MNE activity, in: International Business Review, 9, 2, 163-190.

Dunning, J.H./Lundan, S.M. (2008): Institutions and the OLI paradigm of the multinational enterprise, in: Asia Pacific Journal of Management, 25, 4, 573-593.

Ernst \& Young (2004): Mittelstandsbarometer 2004. Der deutsche Mittelstand - Stimmungen, Themen, Perspektiven. Stuttgart: Ernst \& Young.

Etemad, H./Wright, R.W. (2003): Internationalisation of SMEs: toward a new paradigm, Introduction to special issue, in: Small Business Economics, 20, 1, 1-4.

European Commission (2003): The impact of EU enlargement on European SMEs, Observatory of European SMEs, 6, Luxembourg: European Commission.

Fillis, I. (2001): Small firm internationalisation: an investigative survey and future research directions, in: Management Decision, 39, 3, 767-783.

Fink, M./Kraus, S. (2007): Mutual trust as a key to internationalisation of SMEs, in: Management Research News, 30, 9, 647-688.

Hennart, J.F. (1993), Explaining the 'Swollen Middle': Why most transactions are a mix of market and hierarchy, in: Organization Science, 4, 4, 529-547.

Hollenstein, H. (2005): Determinants of international activities: are SMEs different?, in: Small Business Economics, 24, 5, 431-450.

Johanson, J./Vahlne, J.E. (2003): Business relationship learning and commitment in the internationalisation process, in: Journal of International Entrepreneurship, 1, 1, 83-101.

Johanson, J./Vahlne, J.E. (1990): The mechanism of internationalisation, in: International Marketing Review, 7, 4, 11-24. 
Johanson, J./Vahlne, J.E. (1977): The internationalisation process of the firm: a model of knowledge development and increasing foreign market commitments, in: Journal of International Business Studies, 8, 1, 23-32.

Johanson, J./Wiedersheim-Paul, F. (1975): The internationalisation of the firm: four Swedish cases, in: Journal of Management Studies, 12, 3, 305-322.

Kaufmann, F./Kokalj, L./May-Strobl, E. (1990): EG-Binnenmarkt. Die grenzüberschreitende Kooperation mittelständischer Unternehmen. Stuttgart: Poeschel.

Kay, N. (1991): Industrial collaborative activity and the completion of the internal Market, in: Journal of Common Market Studies, 29, 4, 347-362.

Kotha S./Rindova, V.P./Rothaermel, F.T. (2001): Assets and actions: firm-specific factors in the internationalisation of U.S. internet firms, in: Journal of International Business Studies, 32, 4, 769-791.

Krätke, S. (1999): Regional integration or fragmentation? The German-Polish border region in a new Europe, in: Regional Studies, 33, 7, 631-641.

Krugman, P. (1991): Geography and Trade. Cambridge: MIT Press.

Leick, B. (2007): Die Rolle grenzüberschreitender Unternehmenskooperationen im Grenzraum Südwestsachsen-Nordböhmen im Zuge der EU-Osterweiterung. Freiberg: Technische Universität Freiberg.

Lu, J.W./Beamish, P. (2001): The internationalisation and performance of SMEs, in: Strategic Management Journal, 22, 6/7, 565-586.

Meyer, K.E./Gelbuda, M. (2006): Process perspectives in international business research in CEE, in: Management International Review, 46, 2, 143-164.

Myant, M. (1996): Successful transformations? The creation of market economies in Eastern Germany and the Czech Republic. Cheltenham: Edward Elgar.

Niebuhr, A./Stiller, S. (2004): Integration effects in border regions: a survey of economic theory and empirical studies, in: Jahrbuch für Regionalwissenschaft, 24, 1, 3-21.

Noteboom, B. (1993): Firm size effects on transaction costs, in: Small Business Economics, 5, 4, 283-295.

O'Grady, S./Lane, W. (1996): The Psychic Distance paradox, in: Journal of International Business Studies, 27, 2, 309-333.

Peng, M.W. (2006): Global strategy. Cincinnati: South-Western-Thomson.

Porter, M.E. (2001): Location, competition, and economic development: local clusters in a global economy, in: Economic Development Quarterly, 14, 1, 15-34.

Porter, M.E. (1990): The competitive advantage of nations. London: MacMillan.

Radosevic, S./Sadowski, B.M. (2004): International industrial networks and industrial restructuring in Central Eastern Europe. New York: Springer.

Rangone, A. (1999): A resource-based approach to strategy analysis in small-medium sized enterprises, in: Small Business Economics, 12, 3, 233-248.

Shaw, V./Darroch, J. (2004): Barriers to internationalisation: a study of entrepreneurial new ventures in New Zealand, in: Journal of International Entrepreneurship, 2, 4, 327-343. 
Söllner, A. (2007): The role of relationships in determining foreign entry modes, in: Journal of Business Market Management, 1, 2, 135-149.

Steen, J.P./Liesch, P.W. (2007): A note on Penrosean growth, resource bundles and the Uppsala model of internationalisation, in: Management International Review, 47, 2, 193-206.

Vatne, W. (1995): Local resource mobilisation and internationalisation strategies in small and medium sized enterprises, in: Environment and Planning, 27, 1, 63-80.

Welch, D.E./Welch, L.S. (2008): The importance of language in international knowledge transfer, in: Management International Review, 48, 3, 339-360.

Wernerfelt, B. (1984): A resource-based view of the firm, in: Strategic Management Journal, $18,7,171-180$.

Westhead, P./Wright, M./Ucbasaran, D. (2001): The internationalisation of new and small firms: a resource-based view, in: Journal of Business Venturing, 16, 4, 333-358.

Williamson, O.E. (1991): Comparative economic organization: the analysis of discrete structural alternatives, in: Administrative Science Quarterly, 36, 2, 269-296.

Williamson, O.E. (1975): Markets and hierarchies: analysis and antitrust implications. New York: Free Press.

Wu, F. (ed.) (2007): Overcoming export manufacturers' dilemma in international expansion, in: Journal of International Business Studies, 38, 2, 283-302.

Zain, M./Ng, S.I. (2006): The impacts of network relationships on SMEs' internationalisation process, in: Thunderbird International Business Review, 48, 2, 183-205.

Zanger, C./Hodicova, R./Gaus, H. (2008): Psychic Distance and cross-border co-operation of SMEs: an empirical study on Saxon and Czech entrepreneurs' interest in co-operation, in: Journal for East European Management Studies, 13, 1, 40-62. 